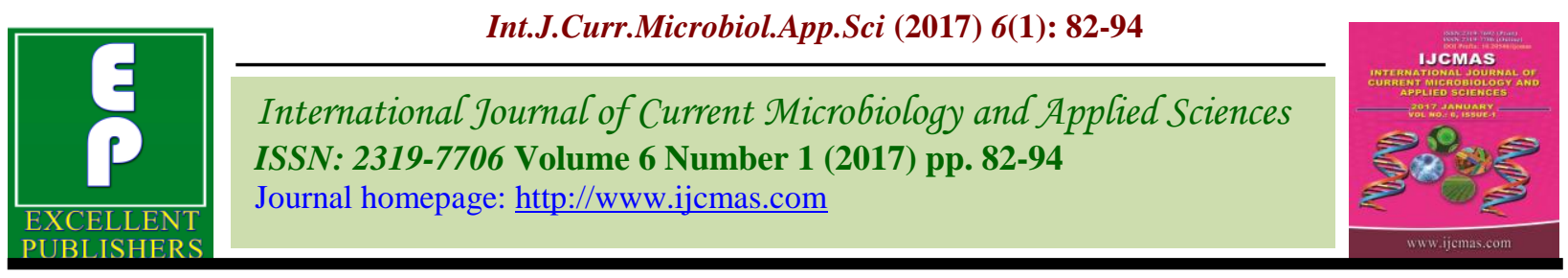

Original Research Article

http://dx.doi.org/10.20546/ijcmas.2017.601.011

\title{
Phytochemical Screening, HPTLC and GCMS Profile of Acacia catechu (L.f) Willd Hydroethanolic Leaf Extract
}

\author{
B. Ramesh* and V. Jayabharathi \\ Department of Biochemistry, PSG College of Arts and Science, Coimbatore, India \\ *Corresponding author
}

\section{A B S T R A C T}

\begin{tabular}{|l|}
\hline Ke y w o r d s \\
Acacia catechu (L.f) \\
Willd, \\
Hydroethanolic leaf \\
extract, HPTLC, \\
GCMS and \\
Phytoconstituents. \\
\hline Article Info \\
\hline $\begin{array}{l}\text { Accepted: } \\
\text { 09 December } 2016 \\
\text { Available Online: } \\
\text { 10 January } 2017\end{array}$ \\
\hline
\end{tabular}

Keywords

Acacia catechu (L.f) Willd,

Hydroethanolic leaf extract, HPTLC,

GCMS and

Phytoconstituents.

Article Info

\section{Introduction}

Medicinal plants are commonly used for the treatment of various ailments, as they are considered to have advantage over the synthetic drugs, that are much expensive and known to have harmful side effects (Akinmoladun et al., 2007). The biologically active phytochemical constituents include alkaloids, tannins, terpenoids, flavonoids and steroids that make specific physiological action on the human body.

\section{Acacia catechu (L.f) Willd (family:} Leguminosae) is widely distributed throughout Asia. Various pharmacological activities reported for the plant include immuno modulatory, hypoglycemic, antimycotic, antifungal, antiviral, antibacterial, anti-inflammatory and antioxidant activities (Singh et al., 1976; Ray et al., 2006; Wang et al., 2006). High Performance Thin Layer Chromatography (HPTLC) is an efficient quality assessment tool that allows the separation and detection of a broad number of phytochemical compounds (Malliga et al., 2015).

The HPTLC fingerprints could be used as an analytical tool for quality control and for determining the bioactive phytocomponents from the herbal medicine (Goodarzi et al., 2013). Gas Chromatography Mass Spectroscopy (GCMS) is the most commonly 
used technique for the identification and quantification of unknown organic compounds in a complex mixture that can be determined by matching the spectra with reference spectra (Ronald Hites, 1997). The present study was sought to investigate the phytochemical and HPTLC profile as well as GCMS analysis of Acacia catechu (L.f) Willd hydroethanolic leaf extract.

\section{Materials and Methods}

\section{Plant collection and preparation of extract}

The plant Acacia catechu (L.f) Willd was collected from Kanjikode, Kerala, identified and certified by a taxonomist at Botanical Survey of India (BSI), Tamil Nadu Agricultural University, Coimbatore, (Plant identification No. BSI/SRC/5/23/20142015/Tech/699).

The leaves of Acacia catechu (L.f) Willd were shade dried and ground to a course powder by mechanical device. The extract was prepared using different solvents viz., peteroleum ether, chloroform, acetone, ethanol, 50\% hydroethanol and water by cold maceration process. The filtrate was used for the preliminary phytochemical analysis (Khandelwal, 2005). Further studies were carried out using the $50 \%$ hydroethanolic extract, prepared using soxhlet apparatus. The extract was condensed to dryness using rotary evaporator and the crude residue obtained (15 $\% \mathrm{w} / \mathrm{w})$ was stored in an air tight container until use.

\section{Quantitative phytochemical screening}

For establishing the phyto-constituents, the extract was subjected to quantitative phytochemical tests as per the standard procedure.
HPTLC analysis of Acacia catechu (l.f) Willd hydroethanolic leaf extract (Shah $e t$ al., 2008)

High performance thin layer chromatography is an automated form of TLC, used to purify the biologically active compounds qualitatively and quantitatively. It has better analytical precision and accuracy, where both sample and standard are processed simultaneously (Sutar et al., 2002).

\section{Sample preparation and application}

The plant extract $25 \mathrm{mg}$ was dissolved in $250 \mu 1$ of $50 \%$ hydroethanol and centrifuged at $3000 \mathrm{rpm}$ for $5 \mathrm{~min} .0 .1 \mu \mathrm{l}$ of this solution and $2.0 \mu \mathrm{l}$ of standard solution were loaded as $5 \mathrm{~mm}$ band length in the $2 \times 10 \mathrm{~cm}$ Silica gel 60F254 TLC plate using Hamilton syringe and CAMAG LINOMAT 5 instrument.

\section{Spot development and photo- documentation}

The sample loaded plate was kept in TLC twin trough developing chamber (after saturation with solvent vapor) with the respective mobile phase (alkaloids, flavonoids, tannins and phenolics separately for each profile) and the plate was developed upto $90 \mathrm{~mm}$. The developed plate was dried by hot air to evaporate solvents from the plate. The plate was kept in a photo-documentation chamber (CAMAG REPROSTAR 3) and captured the images at UV 366nm / day light.

\section{Derivatization and scanning}

The developed plate was sprayed with respective spray reagent and dried at $100^{\circ} \mathrm{C}$ in hot air oven. The plate was photo-documented in day light/UV366nm mode using photodocumentation (CAMAG REPROSTAR 3) chamber. After derivatization, the plate was fixed in scanner stage (CAMAG TLC 
SCANNER 3) and scanning was done at UV $366 \mathrm{~nm} /$ day light. The peak chromatogram and peak densitogram were noted using the software WINCATS 1.3.4 version.

\section{Gas chromatography mass spectral analysis (GCMS) (Vanitha et al., 2011)}

GC-MS studies of medicinal plants are used for the analysis of non polar components, volatile essential oil, fatty acids, lipids (Jie and Choi, 1991) and alkaloids (Betz et al., 1997). GC-MS analysis of the plant extract was carried out using GC SHIMADZU QP2010 system and gas chromatograph interfaced to a Mass Spectrometer (GC-MS) equipped with Elite-1 fused silica capillary column (Length : $30.0 \mathrm{~m}$, Diameter : $0.25 \mathrm{~mm}$, Film thickness : $0.25 \mu \mathrm{m}$ composed of $100 \%$ Dimethyl poly siloxane).

For detection of the spectra, an electron ionization energy system with ionization energy of $70 \mathrm{eV}$ was used. Helium gas $(99.999 \%)$ was used as the carrier gas at a constant flow rate of $1.51 \mathrm{ml} / \mathrm{min}$ and an injection volume of $2.0 \mu \mathrm{l}$ was employed. The injector and the ion source temperature were $200^{\circ} \mathrm{C}$. The oven temperature was programmed from $70^{\circ} \mathrm{C}$ (isothermal for 2 min.), with an increase of $300^{\circ} \mathrm{C}$ for 10 minutes. Mass spectra were taken at $70 \mathrm{eV}$; a scan interval of 0.5 seconds with scan range of $40-1000 \mathrm{~m} / \mathrm{z}$. The running time of the chromatogram was 35 minutes. The relative percentage amount of each component was calculated by comparing its average peak area to the total areas.

Software for mass spectra and chromatogram were GC MS solution ver. 2.53. The spectrum of the unknown component was compared with the spectrum of the known components, stored in the WILEY8 library. The name, molecular weight and molecular formula of the test material were identified.

\section{Result and Discussion}

The qualitative phytochemical analysis of Acacia catechu (L.f) Willd leaf extract revealed the presence of carbohydrates, proteins, thiols, tannins, total phenolics, alkaloids, flavonoids and glycosides as shown in the table -1 .

In the quantitative analysis, the primary metabolites like carbohydrates, protein and total free amino acids were found to be $756 \mu \mathrm{g} / \mathrm{ml}$, $\quad 396 \mu \mathrm{g} / \mathrm{ml}$ and $198 \mu \mathrm{g} / \mathrm{ml}$ respectively as represented in the figure-1. Carbohydrates are biological macromolecules that not only serve as a source of energy but also possess antioxidant activity by which protects the cells against reactive oxygen species, chronic and degenerative diseases (Bin Li et al., 2012). Proteins are primary components of living organisms and are essential to maintain the structural and functional aspects of life including the growth and development (Bhumi and Savithramma, 2014). The amino acids are involved in the synthesis of proteins, amines, alkaloids, vitamins, enzymes and terpenoids (Ibrahim et al., 2010).

The secondary metabolites like flavonoids, tannins and total phenolics were quantified as $82 \mu \mathrm{g} / \mathrm{ml}, \quad 67.5 \mu \mathrm{g} / \mathrm{ml}$ and $\quad 42.5 \mu \mathrm{g} / \mathrm{ml}$ respectively as represented in figure-1. Flavonoids are powerful water soluble antioxidant, which helps in prevention of oxidative cell damage (Loots et al., 2007) through scavenging or chelating process (Kessler et al., 2003). Tannins are polyphenolic compounds that are responsible for the prevention of chronic diseases (Vasundhara et al., 2013). The hydroxyl groups of phenolic compounds act as hydrogen donors, react with oxygen and nitrogen species, thereby break the cycle of generation of new free radicals (Pereira et al., 2009). 


\section{HPTLC fingerprinting profile for alkaloids}

The HPTLC analysis of the plant extract for alkaloids (figure-2a) showed yellow and brownish yellow coloured zones at $366 \mathrm{~nm}$, which revealed the presence of 6 polyvalent phytoconstituents with the $\mathrm{Rf}$ values that ranged from $0.06-0.94$. The component with $\mathrm{Rf}$ values of 0.06 and 0.35 were found to be more predominant with area spanning 131 and 533.3 respectively. The $\mathrm{Rf}$ value and peak area for standard colchicine were found to be 0.53 and 14929.3. The Rf value of 4th peak (0.35) coincide with the standard. The corresponding densitogram is presented in (figure-2b). Alkaloids have physiological and medicinal properties (Hounsome et al., 2008). Alkaloids possess antidiabetic and antibacterial properties (Akinyeye et al., 2014).

\section{HPTLC fingerprinting profile for flavonoids}

In flavonoids profile, yellow, yellowish blue colored zones were observed at $366 \mathrm{~nm}$ (figure-3a), which revealed the presence of 6 polyvalent phytoconstituents with the $\mathrm{Rf}$ values ranged from $0.15-0.96$. The component with $\mathrm{Rf}$ values of 0.45 and 0.83 were found to be more predominant with area spanning 2570.8 and 2389.7 respectively.

Table.1 Qualitative phytochemical screening of Acacia catechu (L.f) Willd leaves extract

\begin{tabular}{|l|c|c|c|c|c|c|}
\hline TESTS & WATER & ETHANOL & $\begin{array}{l}\text { HYDRO } \\
\text { ETHANOL }\end{array}$ & ACETONE & BENZENE & $\begin{array}{l}\text { PET. } \\
\text { ETHER }\end{array}$ \\
\hline CARBOHYDRATE & & & & & & \\
\hline Fehlings Test & + & + & + & + & + & + \\
\hline Benedicts Test & + & + & + & + & + & - \\
\hline Molischs Test & + & + & + & + & + & - \\
\hline PROTEIN & & & & & & \\
\hline Biuret Test & + & + & + & + & + & - \\
\hline Ninhydrin Test & + & - & + & - & - & + \\
\hline THIOLS & & & & & & \\
\hline Ellmans Test & + & + & ++ & ++ & + & - \\
\hline ALKALOIDS & & & & & & \\
\hline Dragendroffs Test & - & - & + & ++ & + & - \\
\hline Wagners Test & ++ & + & ++ & + & + & - \\
\hline Meyers Test & + & - & ++ & + & + & + \\
\hline PHENOLICS & & & & & & \\
\hline Ferric chloride Test & ++ & ++ & ++ & ++ & ++ & - \\
\hline Lead Acetate Test & + & - & ++ & - & + & + \\
\hline Libermanns Test & + & - & + & - & + & + \\
\hline GLYCOSIDES & & & & & & \\
\hline Legals Test & ++ & ++ & ++ & ++ & ++ & - \\
\hline Killer Killani Test & ++ & - & - & + & + & + \\
\hline TANNINS & & & & & & \\
\hline Ferric Chloride Test & ++ & ++ & ++ & ++ & ++ & - \\
\hline Lead Acetate Test & ++ & + & ++ & - & - & + \\
\hline FLAVONOIDS & & & & & & + \\
\hline $\begin{array}{l}\text { Alkaline Reagent } \\
\text { Test }\end{array}$ & + & + & ++ & ++ & + & + \\
\hline
\end{tabular}

$(++)=$ highly present; $(+)=$ present $(-)=$ absence of phytochemicals. 
Table.2 Phytocomponents of Acacia catechu (L.f) Willd by GCMS analysis with the activity profile

\begin{tabular}{|c|c|c|c|c|}
\hline $\begin{array}{l}\text { S. } \\
\text { No }\end{array}$ & $\begin{array}{l}\text { Ret. } \\
\text { Time }\end{array}$ & Name of the compound & $\begin{array}{c}\text { Area } \\
\%\end{array}$ & Activity \\
\hline 1. & 13.275 & Benzenamine, 3 ethoxy & 1.13 & $\begin{array}{l}\text { Antibacterial and antifungal activity } \\
\text { (Kaura and Kaura 2012). }\end{array}$ \\
\hline 2. & 15.092 & 12-Methoxy-19-Norpo Docarpa & 3.73 & $\begin{array}{l}\text { Anticancer activity (Antonio Salatino } \\
\text { et al., 2007). }\end{array}$ \\
\hline 3. & 25.083 & $\begin{array}{l}\text { Furo }[2,3-\mathrm{d}] \text { Pyrimidine- } 4,6 \\
{[5 \mathrm{H}, 7 \mathrm{H}] \text {-dion }}\end{array}$ & 10.20 & $\begin{array}{l}\text { Antifungal and antibacterial activity } \\
\text { (Sambavekar et al., 2014). }\end{array}$ \\
\hline 4. & 26.158 & $\begin{array}{l}\text { 2-Methyl-1,2,3,4-tetrahydro- } \\
\text { beta-carboline }\end{array}$ & 16.26 & $\begin{array}{l}\text { Antioxidant activity (Thomas Herraiz, } \\
\text { 1999). }\end{array}$ \\
\hline 5. & 26.242 & 2-Napthalenamine & 3.36 & Antioxidant activity ( IARC, 2010). \\
\hline 6. & 26.533 & $\begin{array}{l}\text { Phthalic acid, 6-ethyl-3-Octyl } \\
\text { butyl ester }\end{array}$ & 1.41 & $\begin{array}{l}\text { Antimicrobial activity (Gayathri } \\
\text { Gunalan et al., 2014). }\end{array}$ \\
\hline 7. & 26.650 & $\begin{array}{l}\text { 1-Methoxy-4-(4-Methoxy } \\
\text { benzene) }\end{array}$ & 3.23 & $\begin{array}{l}\text { Antimicrobial activity (Panagal Mani et } \\
\text { al., 2011). }\end{array}$ \\
\hline 8. & 26.742 & Pthalic acid, butyl 2- pentyl ester & 4.35 & $\begin{array}{l}\text { Antimicrobial activity (Gayathri } \\
\text { Gunalan et al., 2014). }\end{array}$ \\
\hline 9. & 26.883 & Hexadecanoic acid, ethyl ester & 2.58 & $\begin{array}{l}\text { Antioxidant, Hypocholesterolemic } \\
\text { (Dr. Duke's Phytochemical database). }\end{array}$ \\
\hline 10. & 28.425 & Phytol & 1.62 & $\begin{array}{l}\text { Antioxidant activity, Antimicrobial, } \\
\text { anticancer, anti-inflammatory effect } \\
\text { (Amutha Aishwarya Devi and Kottai } \\
\text { Muthu, 2014). }\end{array}$ \\
\hline 11. & 29.125 & $9,12,15$ - Octadecatrienoic acid, & 2.04 & $\begin{array}{l}\text { Anti-inflammatory effect (Rehana } \\
\text { Banu and Nagarajan, 2013). }\end{array}$ \\
\hline 12. & 29.600 & $\begin{array}{l}\text { Butylphosphonic acid, di(4- } \\
\text { methoxy benzene) }\end{array}$ & 14.82 & $\begin{array}{l}\text { Antioxidant activity (Rane Zab and } \\
\text { Anusha bhaskar, 2012). }\end{array}$ \\
\hline 13. & 29.642 & 2-Pyridine carbonitrile, $1,2,5,6$ & 1.26 & $\begin{array}{l}\text { Antimicrobial activity (Borkhataria and } \\
\text { Shah, 2014). }\end{array}$ \\
\hline
\end{tabular}

Fig.1 Quantification of primary and secondary metabolites present in hydroethanolic leaf extract of Acacia catechu (L.f) Willd
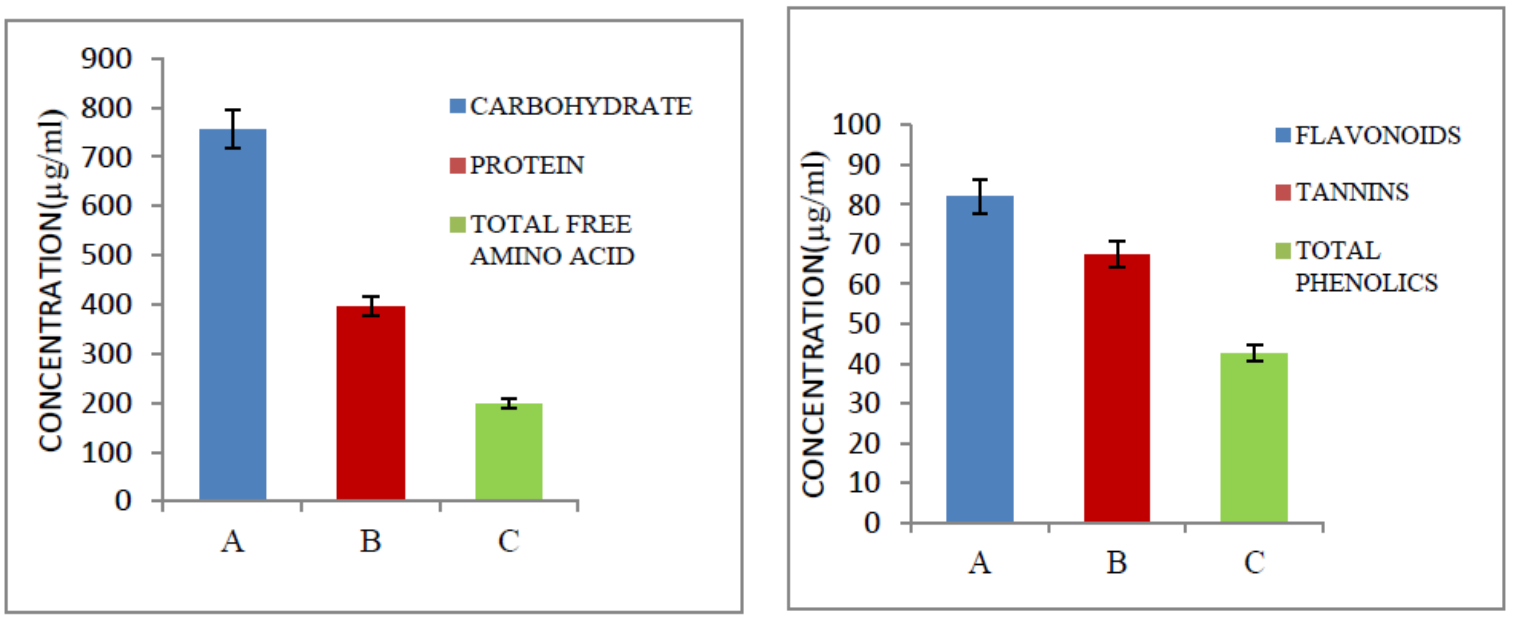

All values are mean \pm standard deviation $(n=3)$. 
Fig.2a Chromatogram of Acacia catechu (L.f) Willd leaf extract for alkaloids

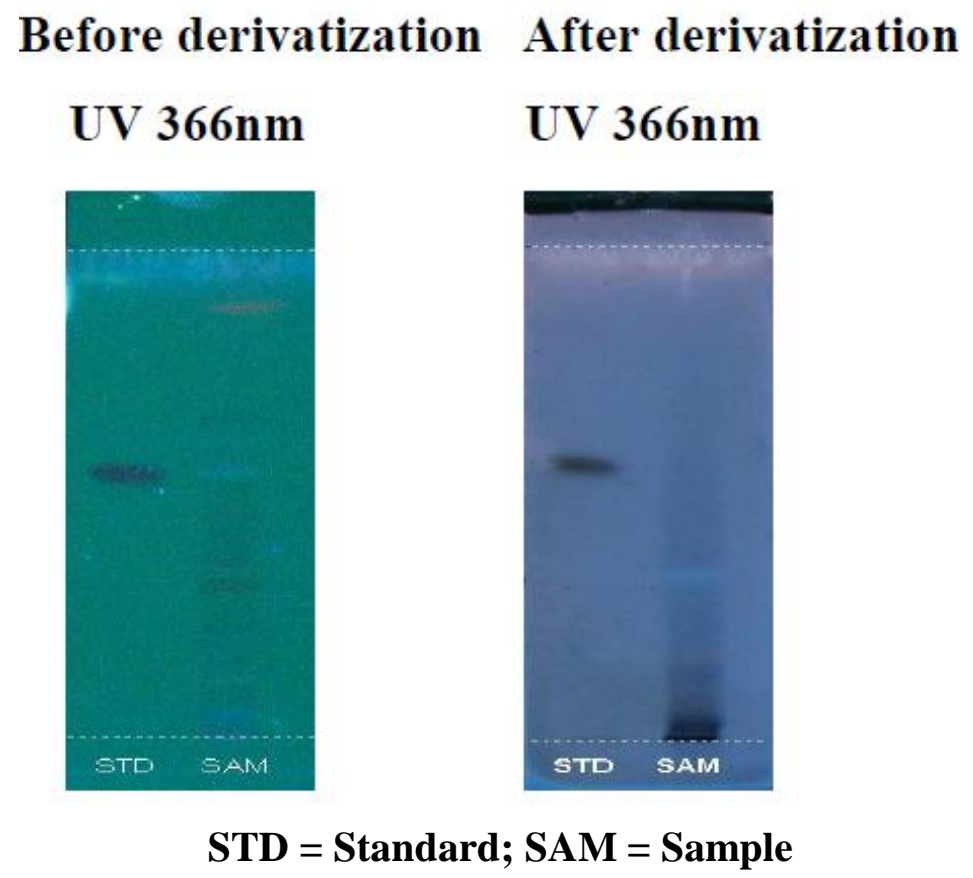

Fig.2b Densitogram display of Acacia catechu (L.f)Willd leaf extract for alkaloids

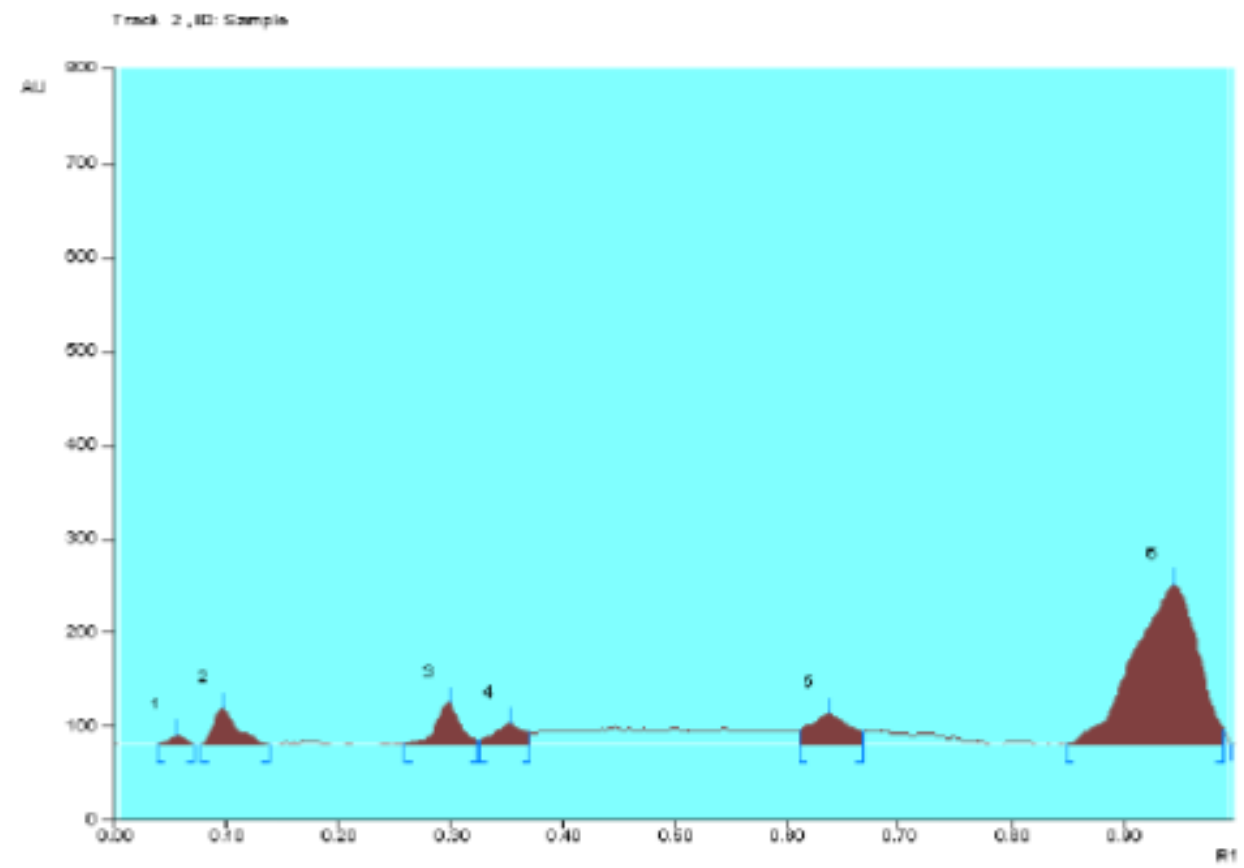


Fig.3a Chromatogram of Acacia catechu (L.f)Willd leaf extract for flavonoids.

\section{Before derivatization After derivatization}

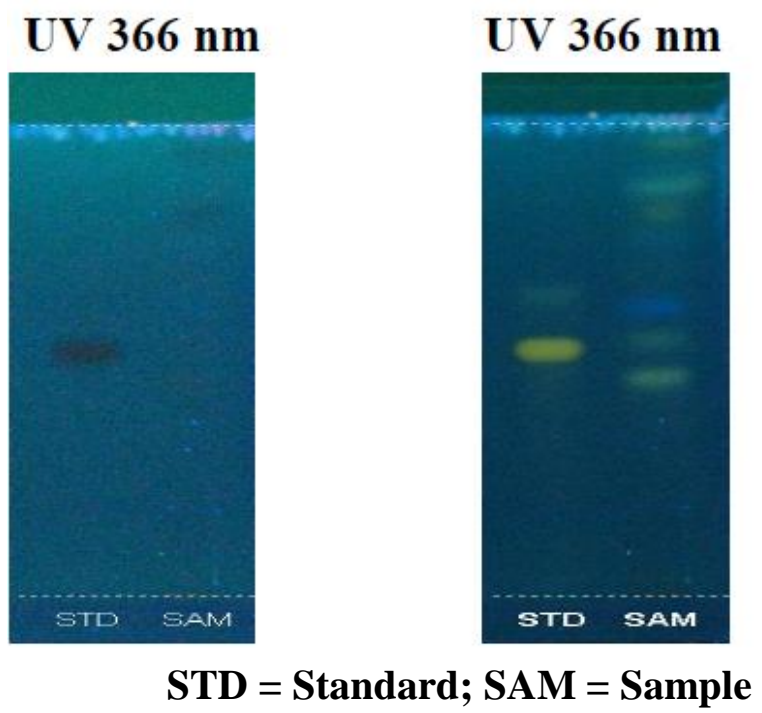

Fig.3b Densitogram display of Acacia catechu(L.f) Willd leaf extract for flavonoids

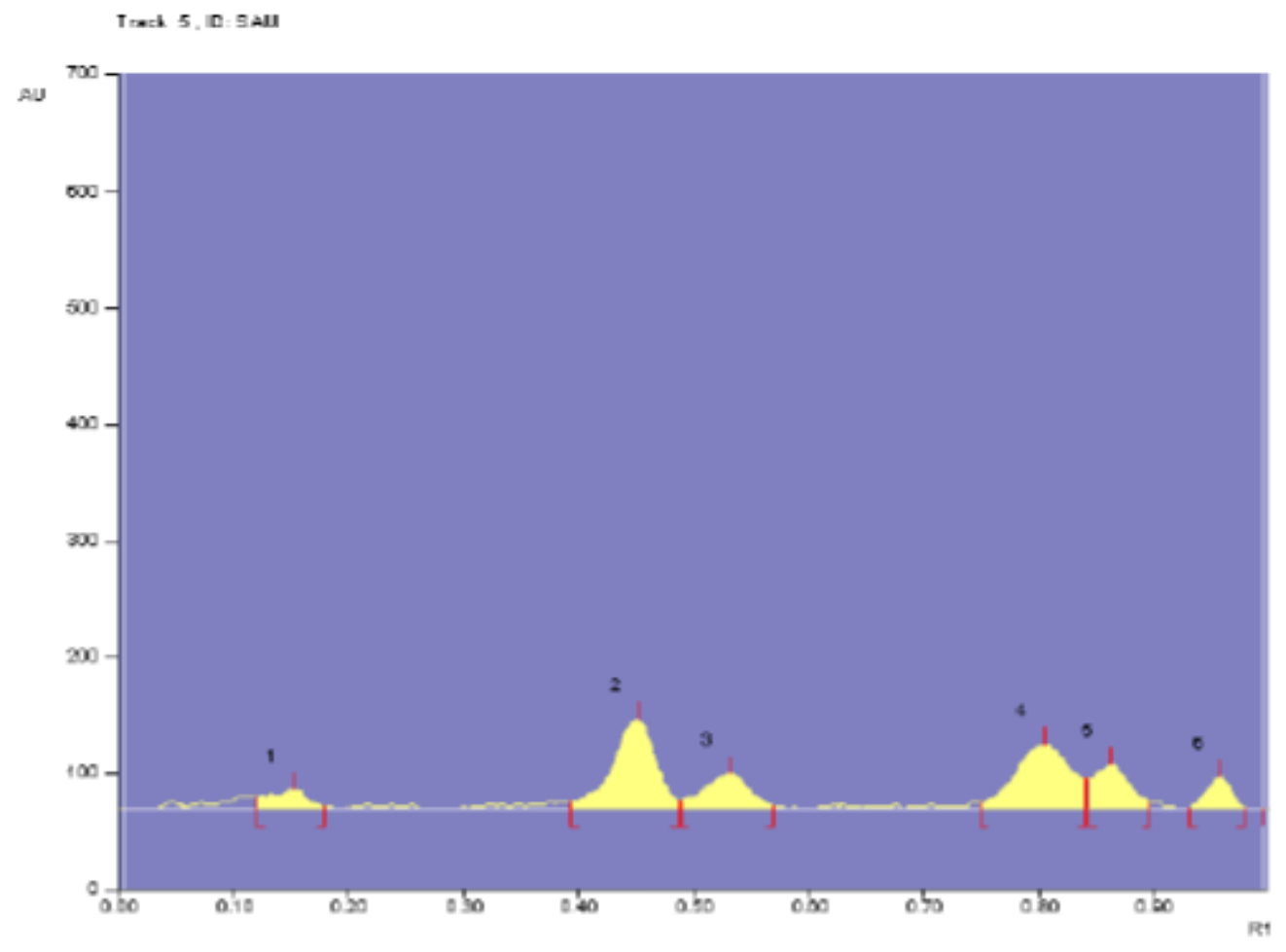


Fig.4a Chromatogram of Acacia catechu (L.f) Willd leaf extract for tannins

\section{Before derivatization After derivatization Day light \\ Day light}

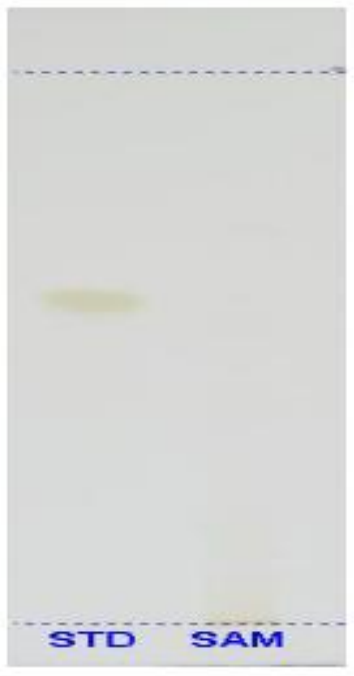

$$
\text { STD }=\text { Standard } ; \text { SAM }=\text { Sample }
$$

Fig.4b Densitogram display of Acacia catechu(L.f) Willd leaf extract for tannins

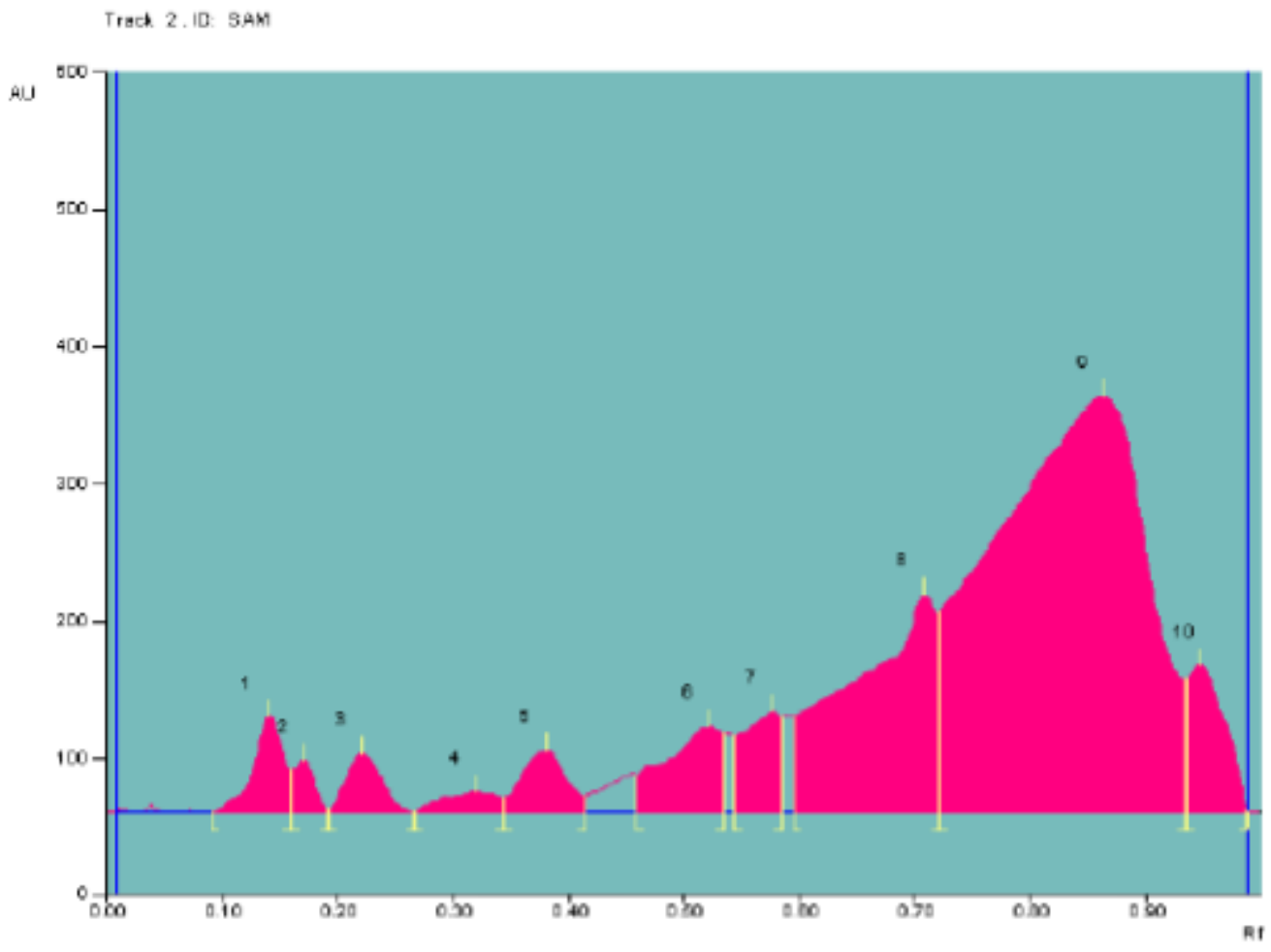


Fig.5a Chromatogram of Acacia catechu (L.f) Willd leaf extract for phenolics

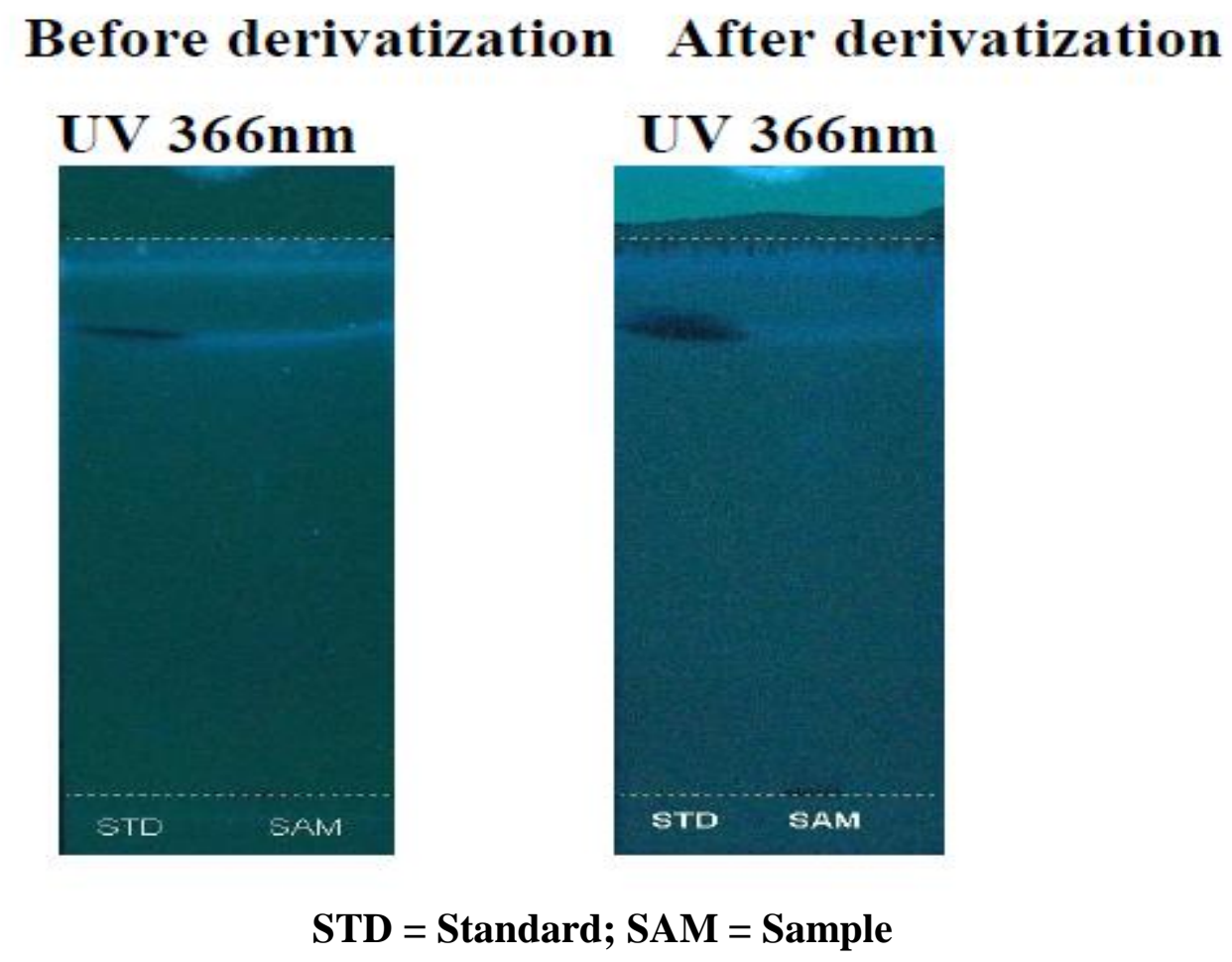

Fig.5b Densitogram display of Acacia catechu (L.f) Willd leaf extract for phenolics

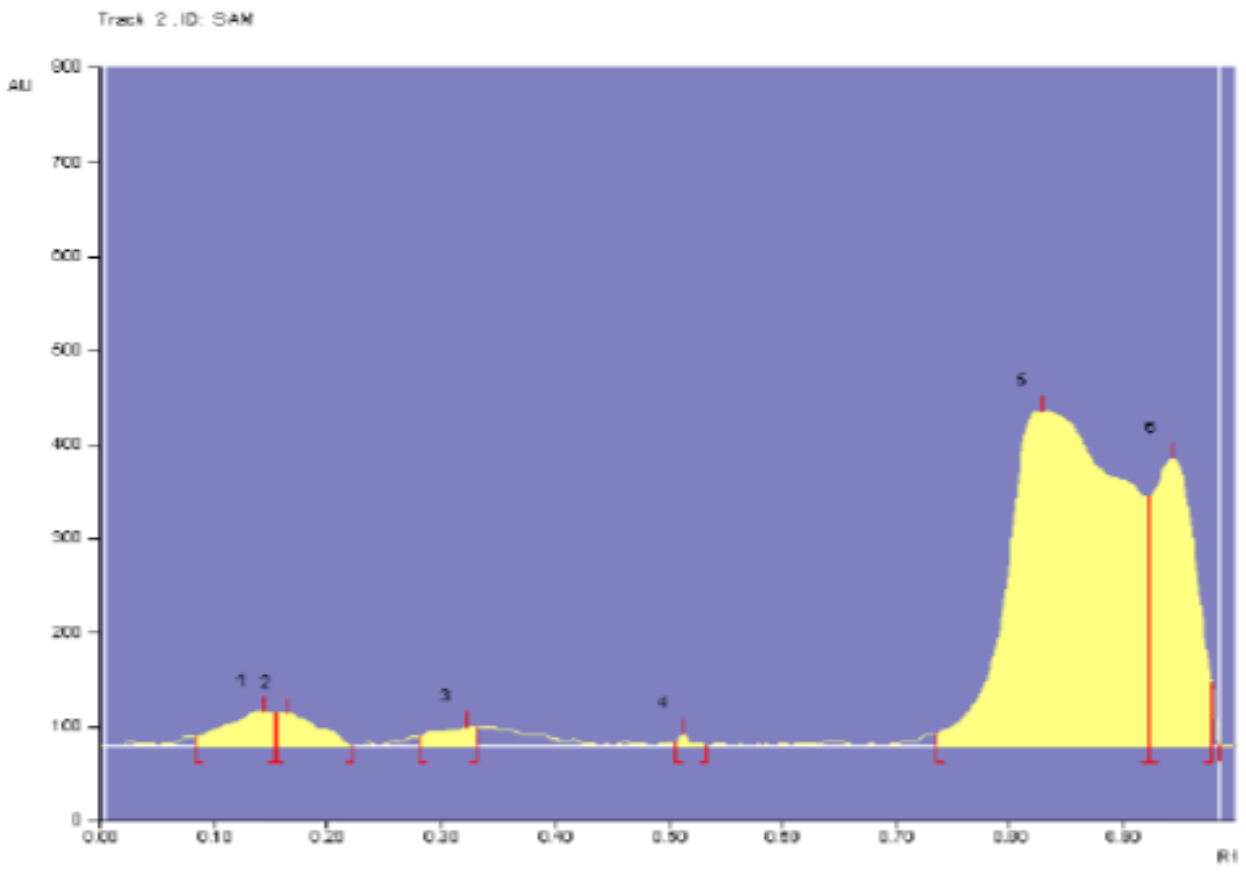


Fig.6 GCMS Chromatogram of Acacia catechu (L.f) Willd leaf extract

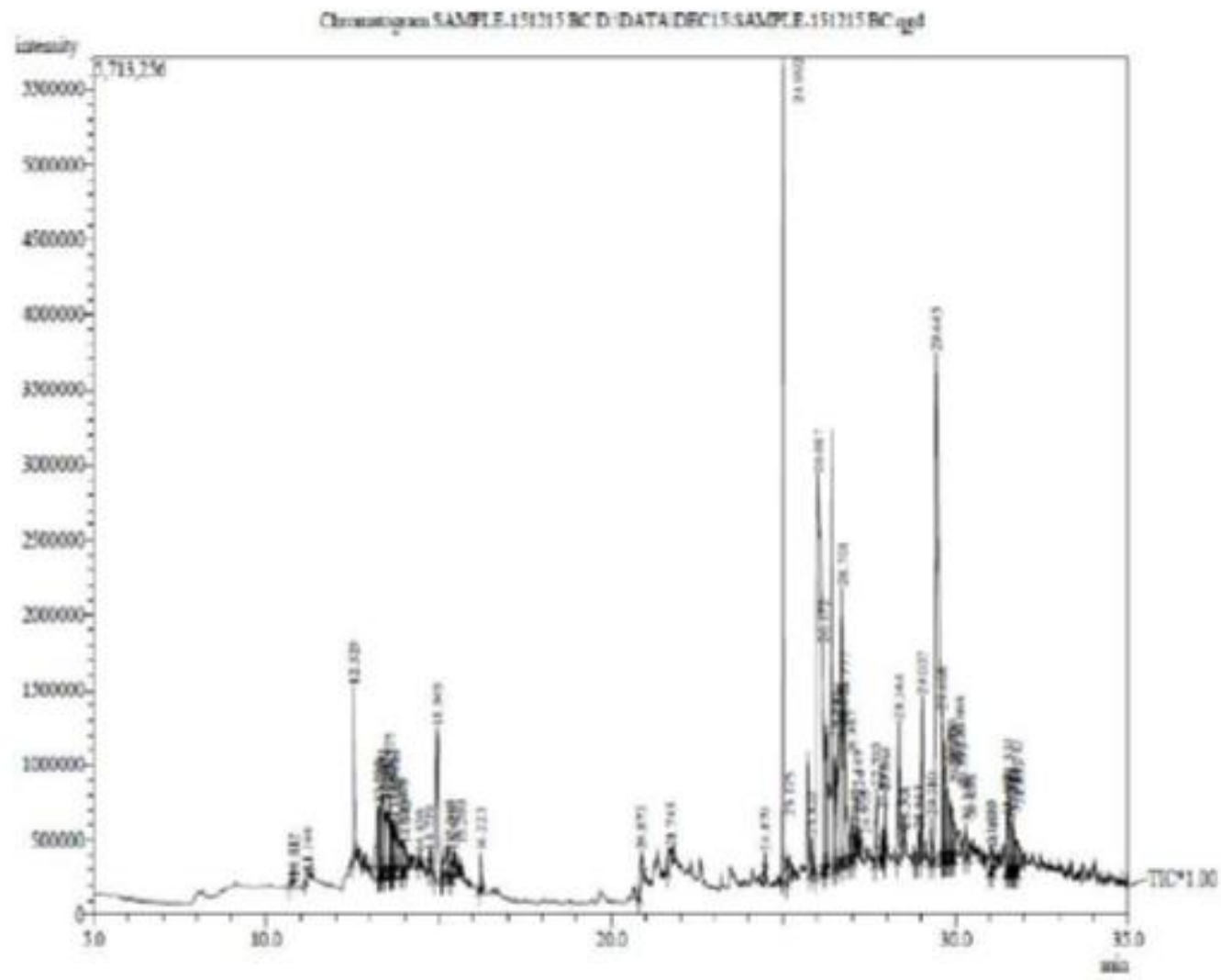

The Rf value and peak area for standard rutin were found to be 0.51 and 18693.9. The Rf value of 3rd peak (0.53) coincide with the standard. The corresponding densitogram is presented in (figure-3b). Flavonoids are known for their antioxidant, antiinflammatory and anti-proliferative activities and therefore used in therapeutic roles (Alzand and Mohamed, 2012).

\section{HPTLC fingerprinting profile for tannins}

The results from HPTLC finger print scanned at wavelength $500 \mathrm{~nm}$ (figure-4a), for tannins revealed 10 polyvalent phyto constituents with the $\mathrm{Rf}$ values ranged from $0.14-0.95$. The component with $\mathrm{Rf}$ values of 0.17 and 0.32 were found to be more predominant with area spanning 612.1 and 637.9 respectively. The Rf value and peak area for standard gallic acid were found to be 0.57 and 18001.1. The
Rf value of 7th peak (0.58) coincide with the standard. The corresponding densitogram is presented in (figure-4b). Tannins possess antimicrobial, anti-allergic, antiinflammatory, anticancer and antineoplastic activities (Rievere et al., 2009).

\section{HPTLC fingerprinting profile for phenolics}

The HPTLC analysis for phenolics recorded in (figure-5a) showed blue brown coloured zones observed at $366 \mathrm{~nm}$ which revealed the presence of 6 polyvalent phytoconstituents with the Rf values ranged from $0.14-0.94$. The component with $\mathrm{Rf}$ values of $0.17,0.51$ and 0.83 were found to be more predominant with area spanning 1136.92 and 34996.9 respectively. The Rf value and peak area for standard catechol were found to be 0.82 and 45901.2. The $\mathrm{Rf}$ value of 5 th peak $(0.83)$ 
coincide with the standard. The corresponding densitogram is presented in (figure-5b). Phenolic compounds possess biological activities such as anticarcinogen, antiinflammation, antiapoptosis, antiaging, antiatherosclerosis, cardiovascular protection and cell proliferation activities (Han et al., 2007).

\section{GCMS analysis of the plant extract}

The GCMS analysis of the plant extract showed 67 peaks (figure-6) that were identified by comparison of the spectra using WILEY and NIST libraries (table-2). The major components in the extract were Benzenamine, 3 ethoxy(1.13\%), 12-Methoxy19-Norpo Docarpa (3.73\%), Furo[2,3-d] Pyrimidine-4,6 [5H,7H]-dion(10.20\%), 2Methyl-1,2,3,4-tetrahydro betacarboline (16.26\%), 2-Napthalenamine(3.36\%), Phthalic acid, 6-ethyl-3-Octyl butyl ester (1.41\%), 1- Methoxy-4-(4-Methoxy benzene) (3.23\%), Pthalic acid, butyl 2- pentyl ester (4.35\%), Hexadecanoic acid, ethyl ester (2.58\%), Phytol (1.62\%), 9,12,15Octadecatrienoic acid (2.04\%), Butylphosphoric acid, di(4-methoxy benzene) $(14.82 \%)$ and 2-Pyridine carbonitrile, 1,2,5,6. (1.26\%).

The phytocomponents with antioxidant activities were found to be 2-Methyl-1,2,3,4 tetrahydro-beta-carboline, 2-Napthalenamine, Hexadecanoic acid, ethyl ester and Phytol. The maximum peak area of $16.26 \%$ was observed for 2-Methyl-1,2,3,4 tetrahydrobeta- carboline, that was reported to have potent antioxidant activity (Thomas Herraiz,1999). From this study, it can be concluded that the hydroethanolic leaf extract of Acacia catechu (L.f) Willd may serve as a new potential source of medicine as antioxidants due to the presence of various phytochemicals and bioactive compounds, which will be useful to treat various diseases.

\section{Acknowledgements}

Financial support University Grants Commissions, in the form of Minor Research Project [No.F MRP: 6281/15 (SERO/UGC)] is acknowledged.

\section{References}

Akinmoladun, A.C., Ibukun, E.O., Afor, E., Obuotor, E.M., and Farombi, E.O. 2007. Phytochemical constituent and antioxidant activity of extract from the leaves of Ocimum gratissimum. Sci. Res. Essay, 2: 163-166.

Akinyeye, A.J., Solanke, E.O., and Adebiyi, I.O. 2014. Phytochemical and antimicrobial evaluation of leaf and seed of Moringa oleifera extracts. Int. J. of Res. in Med. and Health Sci., 4(6): 2307-2083.

Alzand, K.I., and Mohamed, M.A. 2012. Flavonoids: Chemistry, biochemistry and antioxidant activity. J. Pharm. Res., 5: 4013-4012.

Amutha Aishwarya Devi, J., Kottai Muthu, A., 2014. Gas chromatography-mass spectrometry analysis of bioactive constituents in the ethanolic extract of Saccharum spontaneum linn . Int J pharm pharm. sci., 6(2):755-759.

Antonio Salatino, Maria, L., Faria Salatino, and Giuseppina Negri. 2007. Traditional uses, chemistry and pharmacology of Croton species (Euphorbiaceae). J. Braz. Chem. Soc., 18(1):11-33.

Betz, J.M., Gay, M.L., Mossoba, M.M., Adams, S., and Portz, B.S. 1997. Chiral gas chromatographic determination of ephedrinetype alkaloids in dietary supplements containing Má Huáng. Int J AOAC., 80: 303-315.

Bhumi, G., and Savithramma, N. 2014. Screening of pivotal medicinal plants for qualitative and quantitative 
phytochemical constituents. Int. J. pharm. Pharm. sci., 6(3):63-65.

Bin Li, Xan-Jun Meng and Li-wei-sun. 2012. Isolation, chemical characterization and in-vitro antioxidant activities of polysaccharides from Aconiyum Coreanum. J. Med. Plants Res., 6;876883.

Borkhataria, K.N., and Shah, N. 2014. Synthesis, Characterization and antimicrobial activity of Cyanopyridine derivatives with Vanillin. Int. J. Pharma Sci. Res., 5(2):20-24.

Dr. Duke's Phytochemical and Ethnobotanical Databases.

Gayathri Gunalan, Vijayalakshmi Krishnamurthy, and (Late) Ariyamuthu Saraswathi. 2014. GC-MS and HPTLC Fingerprinting of Bauhinia Variegata leaves for anticancer activity. World $J$. Pharmaceutical Res., 3(9):1313-1336.

Goodarzi, M., Russell, P.J., and Heyden, Y.V. 2013. Similarity analysis of chromatographic herbal fingerprints: $A$ review, Analytica Chimica Acta., 804: $16-28$.

Han, X., Shen, T., and Lou, H. 2007. Dietary polyphenols and their biological significance. Int. J. Mol. Sci., 8:950 988.

Hounsome, N., Hounsome, B., Thomas, D., and Edwards-Jones, G. 2008. Plant metabolites and nutritional quality of vegetables. J. Food Sci., 73(4):48-65.

IARC. Some aromatic amines, organic dyes, and related exposures. 2010. IARC Monogr Eval Carcinog Risks Hum., 99: 1-678. [PubMed].

Ibrahim, S.M.M., Taha, L.S., and Farahat, M.M. 2010. Influence of foliar application of peptone on growth, flowering and chemical composition of Helichrysum bracteatum plants under different irrigation intervals. Ozean $\mathrm{J}$. Appl. Sci., 3(1):143-155.
Jie, M.S.F., and Choi, C.Y.C. 1991. Characterization of picolinyl and methyl ester derivatives of isomeric thia fatty acids. J. Int. Fed. Clin. Chem., 3:122.

Kaura, A.K., and Kaura, M. 2012. Synthesis, spectral and comparative antimicrobial study of schiff bases. Int. J. Chemical and Pharmaceutical Sci., 3(4):24-29.

Kessler, M., Ubeaud, G., and Jung, L. 2003. Anti- and pro-oxidant activity of rutin and quercetin derivatives. J. Pharm. Pharmacol., 55:131-142.

Khandelwal, K.R. 2005. Techniques and Experiments. Pune, India: Nirali Prakashan. Practical Pharmacog., 3037.

Loots, D.T., Van Der Westhuizen, F.H., and Botes, L. 2007. Aloe ferox leaf gel phytochemical content, antioxidant capacity, and possible health benefits. $J$. Agric. Food Chem., 55:6891-6896.

Malliga, N., Elangovan, Dhanarajan, M.S., and Elangovan, I. 2015. Preliminary Phytochemical Screening and HPTLC Fingerprinting Profile of Leaf Extracts of Moringa oleifera and Phyllanthus emblica. Int. Res. J. Pharmaceutical and Biosci., (IRJPBS), 2(2):32- 40.

Panagal Mani, M., and Boominathan. 2011. Comparative studies of the antimicrobial activity of crude extracts and fractions from Eugenia caryophyllus against Candida albicans isolate from chronic disease affected patients. Int. J. Institutional Pharmacy and Life Sci., 1(2):36-47.

Pereira, D.M., Valenta, P., Pereira, J.A., and Andrade, P.B. 2009. Phenolics: From Chemistry to Biology. Mol., 14: 22022211.

Rane Zab Anish Kumar, P., Anusha Bhaskar. 2012. Determination of Bioactive components from the Ethanolic Peel extract of Citrus reticulata by Gas chromatography - Mass Spectrometry. Int. J. Drug Dev. \& Res., 4(4):166-174. 
Ray, D.K., Thokchom, I.S. 2006. Antipyretic, antidiarrhoeal, hypoglycaemic and hepato-protective activities of ethyl acetate extract of Acacia catechu in albino rats. Indian J. Pharmacol., 38:408-413.

Rehana Banu, H., and Nagarajan, N. 2013. GC-MS determination of bioactive components of Wedelia chinensis (Osbeck) Merrill. J. Chem. Pharm. Res., 5(4):279-285.

Rievere, C., Van Nguyen, J.H., Pieters, L., Dejaegher, B., Heyden, Y.V., Minh, CV., and Quetin-Leclercq, J. 2009. Polyphenols isolated from antiradical extracts of Mallotus metcalfianus. Phytochemistry, 70:86-94.

Ronald Hites, A. 1997. Gas Chromatography Mass Spectroscopy: Handbook of Instrumental Techniques for Analytical Chemistry, 609-611.

Sambavekar, P.P., Aitawade, M.M., Kolekar, G.B., Deshmukh, M.B., and Anbhule, P.V. 2014. Uncatalysed synthesis of furo $(2,3-\mathrm{d})$ pyrimidine- $2,4 \quad(1 \mathrm{H}, 3 \mathrm{H})$ diones in water and their antimicrobial activity. Indian J. Chem., 53B: 14541461.

Shah, C.R., Suhagia, B.N., Shah, N.J., Patel, D.R., and Patel, N.M. 2008. Stability indicating simultaneous HPTLC method for Olanzapine and Fluoxetine in combined tablet dosage form. Indian $J$. Pharm. Sci., 70(2):251-255.

Singh, K.N., Mittal, R.K., and Barthwal, K.C. 1976. Hypoglycemic activity of Acacia catechu, Acacia suma, and Albizzia odoratissima seed diets in normal albino rats. Indian J. Med. Res., 64: 754-757.

Sutar, A.C., Sohoni, D.P., Banavaliker, M.M., and Blyani, M.K. 2002. HPTLC methods for quantitative estimation of genistein and daidzein with its glycosides in Glycine max. Indian Drugs, 39:434-434.

Thomas Herraiz, J. 1999. Agric. Food Chem., 47(12): 4883-4887.

Vanitha, K.J., Umadevi, K., and Vijayalakshmi. 2011. Determination of Bioactive Components of Annona squamosa L Leaf by GC- MS Analysis. Int. J. Pharmaceutical Sci. Drug Res., 3(4):309-312.

Vasundhara, S., Garmia, M., Akash, S., Kamlesh, K.R., and Vishwakarma. 2013. A comparative study on quantitative estimation of tannins in Terminalia chebula, Terminalia belerica, Terminalia arjuna and Saraca indica using spectrophotometer. Asian J. Pharmaceutical and Clin. Res., 6(3):148-149.

Wang, Y.H., Wang, W.Y., Chang, C.C., Liou, K.T., Sung, Y.J., Liao, J.F., Chen, C.F., Chang, S., Hou, Y.C., Chou, Y.C., and Shen, Y.C. 2006. Taxifolin ameliorates cerebral ischemia-reperfusion injury in rats through its anti-oxidative effect and modulation of NF-kappa B activation. $J$. Biomed. Sci., 13(1): 127-141.

\section{How to cite this article:}

Ramesh, B., and Jayabharathi, V. 2017. Phytochemical Screening, HPTLC and GCMS Profile of Acacia catechu (L.f) Willd Hydroethanolic Leaf Extract. Int.J.Curr.Microbiol.App.Sci. 6(1): 82-94. doi: http://dx.doi.org/10.20546/ijcmas.2017.601.011 